\title{
3. Fiji: Voiceless in the newsstand
}

\section{COMMIINIARY}

Journalists in Fiji continue to try as best they can, working under trying censorship conditions, to ensure that their readers, listeners, viewers and other audience - the people of Fiji-receive as much information as possible that is relevant to their lives and essential for them to make informed decisions.

\section{SOPHIE FOSTER}

Assistant Editor, Fiji Times, Suva

'YOU are not the same as you were before, 'said the Mad Hatter to Alice.

'You were much more muchier. You've lost your muchness.'

'My muchness?' Alice asks.

'In there, 'the Mad Hatter says, pointing to Alice's heart, 'something's missing'.

Lewis Carroll, Alice in Wonderland, 1865

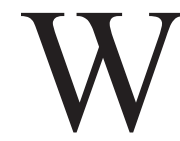

E DON'T need a Mad Hatter to tell us that over the past year in Fiji much ground has been lost in the fight for the universal cause of freedom of expression. And with it is going freedom of the press. For those of us for whom it is a daily reality to come face to face with just how much we have lost-how viewless or voiceless our society has become-it would be easiest to simply succumb and say that the heart has gone out of the journalism profession in Fiji. And yet we find that journalists in Fiji continue to try as best they can, working under very tough conditions, to ensure that their readers, listeners, viewers - the people of Fiji-receive as much information as possible that is relevant to their lives and essential for them to make informed decisions.

\section{Delivering the news}

In considering the various ways to approach this panel discussion, it was clearly very important that the views of journalists in Fiji are represented. So in April, I conducted a survey of mainstream journalists in Fiji to gather first-hand information on the impact of the past 
year of State censorship and control over press freedom. The survey respondents represented around 13.6 percent of the total number of journalists in the country, and just over half of them were women. Every journalist who responded said that they did not feel free to report the news as they found it. What exactly not feeling free to do their job means is journalists in Fiji are being systematically forced into being selective with the types of stories they explore, a direct result of Government censorship since Easter 2009.

Subeditors and news editors-the guardians, if you like, of principled accurate journalism-have seen an obvious trend towards reporters' hands being tied-figuratively. One respondent said: '... gone are the days when a reporter writes a news article and we as subeditors know that it's a balanced report and feel comfortable with it ...' Another respondent lamented that censorship of stories by state officials has made it hard for journalists to produce stories about what is really happening, or to allow for the free expression of the feelings and comments of the people of Fiji over their own situation. I quote: 'These kinds of stories are not allowed ... they want everything to be good and a very positive picture painted all the time. The truth is somewhat hidden by the censorship.' The situation you will find is that journalists in Fiji are being steadily pushed into a position where they have to water down stories to suit censors, which in most cases, results in real stories never being told. It is an extremely frustrating situation - especially for those who know what it is like to work under free media.

\section{Growth of self-censorship}

This brings me to my next point - the growth of self-censorship within the Fiji media industry. With journalists now coming face to face with the fact that the whole truth or freedom of expression is not being fully exercised, some are now having to consider self-censoring stories they work on-because they know that unless they do their stories won't meet the censors' approval. The fact that journalists are beginning to consider this course of actionconsidering going against their professional ethics and beliefs-is a telling factor and a worrying one for the future of freedom of expression in Fiji. But the fact of the matter is that self-censorship is already occurring in mainstream media in Fiji. In the words of one journalist: 'We are restricted in what we can report, especially if it is'negative' news with regard to the economy, crime, 
public service. We also cannot run news items on unions or on human rights advocates unless we tailor the story a certain way that would pass censor's eyes.' Most troublesome for the future of the media industry in Fiji is the fact that the months of hardline tactics against professional journalism seems to be wearing down practitioners. One respondent summed up this new worry, suggesting that to avoid the media being 'told off',

they should just try and just report on what the authority of the day wants them to report on. Let's see how or what they (the Government) are trying to achieve. Because we have tried our media way and we're being told it's wrong. So let's try their way and see. Just try.

\section{The censorship process}

Of all the journalists who responded to the survey last month, 100 percent of them have had stories, pictures, layouts or footage that they or their colleagues worked on censored from publication. One respondent said they had lost count of the number of stories that have been censored: 'It's very frustrating especially when I know that a reporter has done a good job getting balanced news and the fact that it's of public interest. Stressful-the word is not even enough to describe the situation.'

Another respondent said they had a collection of censored articles, with their latest calculations putting the number of censored articles at more than 2000. An example of what journalists have to face, is the treatment provided to an article about an area in the interior of Viti Levu-Fiji's biggest island. In that area-called Yalavou-the people produce a small amount of cash crops as the only source of income. These crops were unable to reach the market because of deteriorating road conditions and a broken bridge. Even public transportation providers stopped operations in the area. So farmers resorted to using bullocks to drag makeshift sleds to cart their crops to the main road. The article began: '... Life drags by an inch at a time in Yalavou ...' Because of that sentence, the respondent said, the article was censored. Another respondent highlighted the fact that censorship seemed to depend on the whims of individual censors, with some stories being allowed in some media and not in others, some passing censorship after being rewritten or even after being presented to other censors. 'There is no guideline on censorship ... it seems to be on a day-to-day basis or on the whim of the censor in charge.' 


\section{Issues targeted by censorship}

Journalists were asked which issues they felt confident could pass censorship. One hundred per cent felt confident that coverage of community issues would be allowed, which would mean stories about school fundraising events, bazaars and clean up campaigns. In the next highest category, 93.3 percent were confident that sporting stories would pass censorship, followed by business, and industries. Stories about women and infrastructure returned a 73.3 percent confidence rating, while health and legislation changes saw 66.7 percent confident of passing censorship, and 53.3 percent confident on social welfare issues. Respondents were least confident that stories on political parties would pass censorship, as well as the military, police and union issues. Only one in three were confident that stories on the economy, employment issues and rape would pass censorship, while only 40 percent were confident that articles concerning crime, the cost of goods and services, and state and Public Service issues would reach readers, viewers and listeners. Just over half of these respondents said that because there was no criteria for censorship, every issue highlighted above could also be dropped from publication if it painted a negative picture. 'It is difficult to pinpoint which ones can pass censorship because most of the issues which I clicked on can also be dropped by the censors... the bottom line is they approve 'positive' stories, the ones that don't tarnish or provide a negative image of the regime.' The journalist goes on to say that a human interest feature can be dropped if it highlighted the high cost of living or poverty.

\section{How journalists respond to censorship}

The survey also attempted to gauge what steps were taken, if any, to ensure that stories, pictures or footage passed censorship. Somewhat surprisingly, given the past year of censorship, 73.3 percent of journalists who responded said they continued to write as normal regardless of whether it would be censored. Not a single respondent said that their stories always passed censorship, while 60 percent said they always ensured there was a Government comment or involvement in the piece. One in five respondents said they did not cover issues that may be banned while 13.3 percent said they did not quote or take pictures of people who may be banned. 


\section{Causes for concern}

Putting aside the ethics of the situation journalists in Fiji are in, in the words of one respondent it is "frustrating writing "positive" notes about issues that have negative implications on the public'. But what is 'even more frustrating' according to the same respondent is 'when the everyday citizen is led to believe that publishing a person's view or an issue against the higher authorities' is inciting civil unrest. Many of the journalists who do the work they do in Fiji, do so because they believe that they are in the midst of delivering a public service and a public good-one that involves them being the watchdog for the average citizen, keeping an eye on injustices, insufficiency, inaction, and highlighting these things for the purpose of making a better Fiji. The survey found that 100 percent of respondents did not believe that the work they did as journalists was a threat to national security. That work is now hampered.

\section{Where to next?}

The vast majority of journalists said they needed censorship measures lifted in order to do their job better. One respondent said: 'Censorship needs to be lifted so we can get on with our jobs, which is to keep the people of Fiji as informed as possible about decisions and stories which affect their lives.' The survey showed 73.3 percent felt that more journalism and other training was necessary and so were better working conditions. Comments in this area centred on concerns over bills, mortgages and mouths to feed, as well as finding work/life balances and handling stress better. Two-thirds felt that access to counselling for stress and other impacts would help, as well as access to more sources of information. In the words of another respondent: 'I can't work freely now. I always have to consider the media censorship that takes place in the country now... I once saw a 60 Minutes programme about a dog barking controller device that is attached to the dog's neck. It sprays a sharp spurt of water to the dog's throat whenever he barks. Just days later, the dog is quiet... I feel like that dog now. I can't even express how I felt for the past months.' When the so-called 'watchdog' is silenced, where to then for freedom of expression, where to for the right to know? Article 19 of the Universal Declaration of Human Rights states that everyone has the right to freedom of expression, through any media, regardless. In Fiji, we live in hope that one day soon we will achieve this. 
Sophie Foster is assistant editor of the Fiji Times in Suva, Fiji. This address was made at the UNESCO World Press Freedom Day Conference at the University of Queensland, Brisbane, 1-3 May 2010 as part of a 'Media freedom in the Pacific' panel. sfoster@fijitimes.com.fj

\section{A凹] COMMUNICATIONS}

\section{POSTGRADUATEJOURNALISM}

Bachelor of Communication Studies(Hons) offers students either an applied or an academic pathway in communication studies. Papers and strands include Asia-Pacificjournalism, digital media, investigativejournalism, public relations and screen writing.

Master of Communications Studies(MCS) is a postgraduateresearch degree offering practical options. Doctorate in Communication Studies (PhD) is a thesis-based research degree granted on the basis of $x$ original and substantive contribution to knowledge. TheFaculty of Designiand Greative Industries encourages and supports innovative interdisciplinary research. The School of Communication Studies has supervising staff whose research interests cover a range of areasencompassing media, politics and ownership, journalism, human communication, newmedia and development, discourse analysis and popular culture.

Email: commstudies国aut.ac.nz Web: www.commstudies.aut.ac.nz

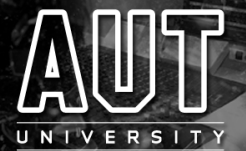


Copyright of Pacific Journalism Review is the property of Auckland University of Technology and its content may not be copied or emailed to multiple sites or posted to a listserv without the copyright holder's express written permission. However, users may print, download, or email articles for individual use.

http://www.aut.ac.nz/depts/commstud/journ/pjrsubs.shtml 